\title{
The importance of emerging chironomids as a food resource for overwintering passerines in an Iberian high altitude lake
}

\author{
Luís Filipe Pires Braz ${ }^{1}$, Bruno Oliveira² ${ }^{2}$ and Samantha Jane Hughes ${ }^{2,3}$
}

${ }^{1}$ Rua do Vale, $n^{\circ}$ 283, Borbela, 5000-063, Vila Real, Portugal.E-mail: luisfbraz@gmail.com ${ }^{2}$ Laboratório de Ecologia Fluvial, University of Trás-os-Montes e Alto Douro, Quinta de Prados, 5000801 Vila Real, Portugal.E-mail: brupa oliveira@hotmail.com

${ }^{3}$ CITAB, University of Trás-os-Montes e Alto Douro, Quinta de Prados, 5000-801 Vila Real, Portugal.

E-mail: shughes@utad.pt

Chironomids form an essential part of the diet of insectivorous birds that feed on emerging aquatic insects in both riparian areas (Lynch et al. 2002, Beck et al. 2013) and other aquatic habitats, providing an important trophic link between the aquatic and the terrestrial environment. High altitude lakes in mountain landscapes are relatively common and valuable habitats that provide vital resources to terrestrial fauna before freezing over in the winter. Chironomids are known to be a major component of the macroinvertebrate fauna of high altitude lakes and are perhaps a particularly important food source during cold weather conditions (Boggero et al. 2006, Füreder et al. 2006, Bouchard et al. 2006).

High altitude lakes are relatively rare on the Iberian Peninsula (Rieradevall and Prat 1999, Hughes et al. 2012). The Picos de Europa mountain range, situated within the Picos de Europa National Park on the northern coast of Spain, is part of the Cantabrian Mountain Range, located in the northwest of Spain. The area, situated in the Eurosiberian biogeographical region, is predominantly calcareous and located within the Atlantic climate domain which has high levels of precipitation $(>1,000 \mathrm{~m})$ in the autumn and winter, mild winters, and cool summers (Moreno et al. 2011). The Covadonga Lakes, a system of two permanent glacial lakes, Enol and La Ercina (1070 m.a.s.l. and 1108 m.a.s.l. respectively) are situated within the National Park in the eastern Cantabrian Mountain Range, in the Asturias principality. Situated in a small catchment $\left(1.5 \mathrm{~km}^{2}\right)$, Lake Enol has a surface area of 12.2 hectares and a maximum depth of $22 \mathrm{~m}$. This landscape, which was previously forested, was cleared by man during prehistoric and historic times to produce the present day alpine meadows and pastures that are typical of the area (Montserrat and Fillat 1990).

A collecting campaign of the chironomids of the high altitude lakes of central Portugal and northern Spain was carried out in November 2013. Snow had already fallen and was accumulating at altitudes above 800 $\mathrm{m}$ in the Cantabrian Mountains. Collections in Lake La Ercina were not possible as the lake already had a considerable layer of solidifying ice resulting from compacted accumulated snowfall on the lake surface (Fig. 1a). No insect activity was observed at the lakeside. In contrast, Lake Enol, only $500 \mathrm{~m}$ from Lake La Ercina, but at lower altitude, had no ice cover at all (Fig. 1b). Collections of exuviae and adults were made on the leeward shore of Lake Enol indicating actively emerging chironomids at the water surface. Exuviae were collected from the water surface using a handnet $(250 \mu \mathrm{m}$ mesh) while adults were taken by hand

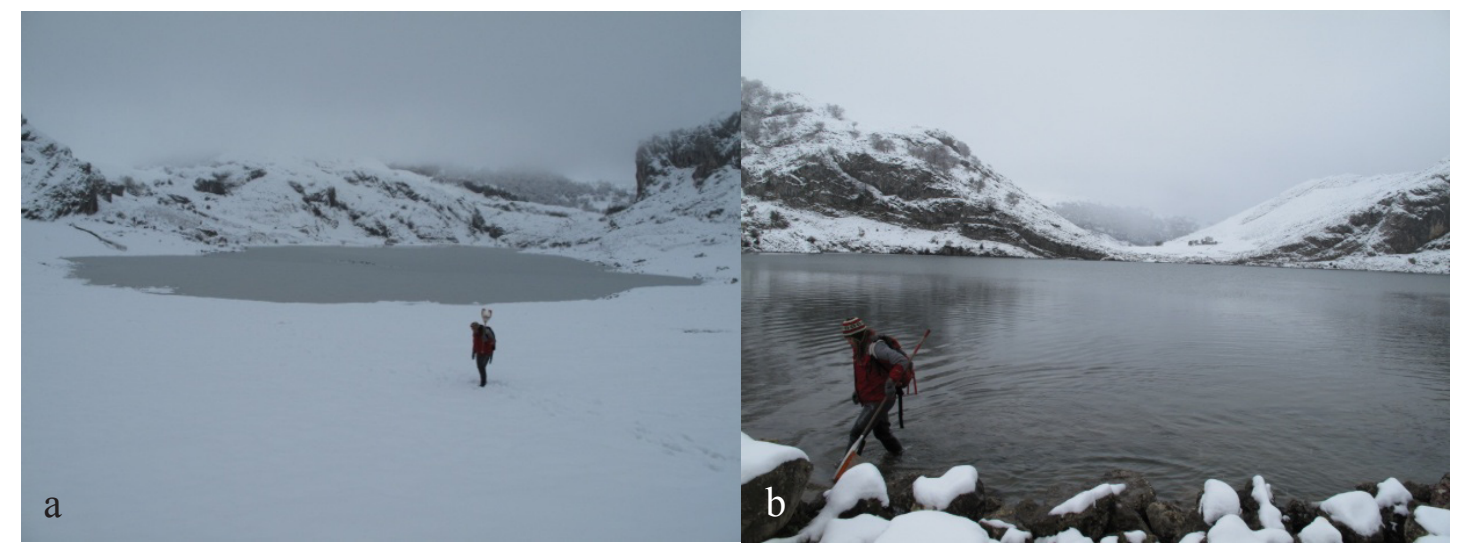

Figure 1. Lakes Ercina and Enol. a, Lake Ercina (1108 m.a.s.1.) in the Picos de Europa National Park, iced over in November 2013; b, Lake Enol (1070 m.a.s.1.) with no ice cover in November 2013. Lake Enol is only 500m distant from Lake Ercina and only ices over for comparatively short periods during the winter. 
from the surface of the snow. All collected material was preserved in situ in $70 \%$ alcohol. Immobile adults were clearly visible resting on snow banks at the lakeside and found up to $100 \mathrm{~m}$ away (Fig. 2a, b) from the lake. No other aquatic insects were observed emerging from Lake Enol during our time collecting along the shore (23 $3^{\text {rd }}$ November 2013). Weather conditions were largely overcast and the ambient temperature was $3^{\circ} \mathrm{C}$, with intermittent periods of snowfall and occasional sunshine. Water temperature was $6.4^{\circ} \mathrm{C}$. Exuviae collected from Lake Enol were identified using non-permanent rapid mounts in alcohol. Initial identifications of exuviae collected from Lake Enol resulted in 10 species, including:

Paratanytarsus bituberculatus (Edwards, 1929)

Tanytarsus gibbosiceps Kieffer, 1922

Corynoneura edwardsi Brundin, 1949

Neozavrelia Pe1 Langton, 1991 (fuldensis Fittkau, 1954 or luteola (Goetghebuer and Thienemann, 1941))

Microtendipes chloris (Meigen, 1818)

Polypedilum (Pentapedilum) sordens (Wulp, 1874)

Stictochironomus histrio (Fabricius, 1794)

Chironomus plumosus (L, 1758)

Metriocnemus obscuripes (Holmgren, 1869)

Pseudorthocladius cf Pe3 Langton, 1991

Some specimens will require additional treatment to elucidate species. Adults have not yet been identified and will be included in a future paper.

While collecting, remarkable field observations were made on the feeding behaviour of three overwintering species of passerines Motacilla alba (White Wagtail), Saxicola rubicola (Common Stonechat), and Erithacus rubecula (European Robin). Individuals of M. alba, S. rubicola and E. rubecula were observed actively feeding on chironomids along the leeward shoreline of Lake Enol. Notably, these species used different feeding strategies. Individuals of E. rubecula remained on the lake margins, actively collecting the recently emerged, resting adult chironomids from the snow surface, which rendered them highly visible to predators (Fig 2a, Fig 2b).

In contrast, individuals of $M$. alba and S. rubicola were seen initially observing the lake surface while perched on rocks along the shoreline, and then would take off to fly in small circuits over the lake surface, stopping to flutter and hover over the water surface in mid-flight to pluck freshly emerging adult chironomids. Motacilla alba is a bird commonly associated with freshwater habitats. In the case of S. rubicola, this behaviour is very unusual since this species is associated with predominantly terrestrial feeding habits. We filmed this behaviour while at Lake Enol (http://www.youtube.com/watch? $\mathrm{v}=\mathrm{z} 7 \mathrm{y} 65 \mathrm{cCCjmo} \&$ feature $=$ you tu.be).

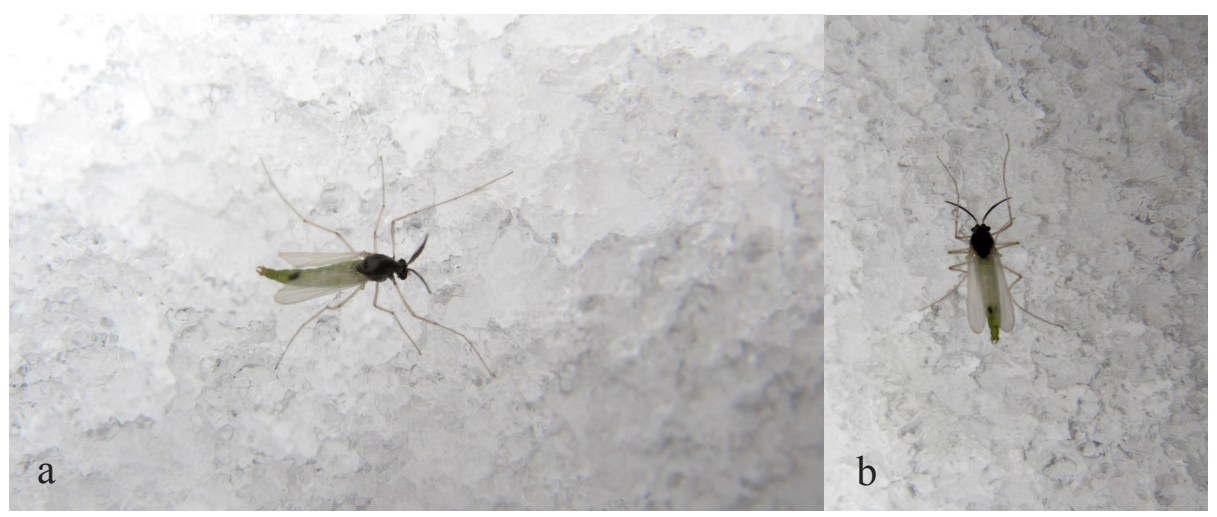

Figure 2. Recently emerged adult male chironomids (not yet identified) rest completely immobile on the snow surface on the leeward shore of Lake Enol. They are highly visible to predators and easily picked off as a result of their immobility. 
Urquhart (2002) describes feeding techniques of S. rubicola in terrestrial habitats. The "aerial sally" describes a short, steep aerial ascent and pursuit of flying insect prey, while the "aerial glean" technique involves plucking insect prey items from surrounding vegetation whilst in flight. "Perch to ground sallying" occurs where ground dwelling prey items are observed from an elevated perch and the bird flies to pluck the prey item from the ground, while "flutter pursuit" is where a bird flies to the prey item and flutters after it along the ground or above it in the air. Perch to ground sallying was also reported by Greig-Smith (1983). No scientific papers were found mentioning stonechats feeding over water in the way we observed on Lake Enol following an extensive online literature search (online searches on Google Scholar 02/12/2013 and Scopus 02/12/2013). On the British Birds Rarities Committee website, we found only a short note digitized from the British Birds Magazine dating back to 1977 (Available at: http://www.britishbirds.co.uk/ search?model=pdf\&id=5180) describing a female or immature stonechat taking food from water. We also found wildlife photos of stonechats feeding on invertebrates through ice holes on a frozen lake in the UK on the website of the wildlife photographer Brian Rafferty (Photos available at: http://brianraffertywildlifephotographer.blogspot.pt/2010/01/stonechats-on-ice-conclusion.html).

During a typical year, Lake Enol is normally frozen over for only 1-3 weeks (Alfredo Nicieza, University of Oviedo, pers. comm.). Our observations on Lake Enol reveal an apparently rare feeding mode of stonechats over open water that appears to be an adaptation and combination of "perch to ground sallying" and "flutter pursuit". Observations also emphasise the extreme importance of emerging adult chironomids as a vital food resource for small overwintering insectivore birds in high altitude lakes that do not freeze over or freeze for only short periods of time. This emphasises the strong aquatic-terrestrial trophic link in high altitude ecosystems during the onset of winter when food resources become scarce.

\section{References}

Lynch, R.J., Bunn, S.E. and Catterall, C.P. 2002. Adult aquatic insects: Potential contributors to riparian food webs in Australia's wet-dry tropics. - Austral Ecology 27: 515-526.

Beck, M.L., Hopkins, W.A. and Jackson, B.P. 2013. Spatial and temporal variation in the diet of Tree swallows: Implications for trace element exposure after habitat remediation. - Archives of Environmental Contamination and Toxicology 65: 575-587.

Boggero, A., Füreder, L., Lencioni, V., Simcic, T., Thaler, B., Ferrarese, U. et al. 2006. Littoral chironomid communities of Alpine lakes in relation to environmental factors. - Hydrobiologia 562 (1): 145-165.

Füreder, L., Ettinger, R., Boggero, A., Thaler, B. and Thies, H. 2006. Macroinvertebrate diversity in Alpine lakes: Effects of altitude and catchment properties. - Hydrobiologia 562 (1): 123-144.

Bouchard Jr, R.W., Carrillo, M.A. and Ferrington Jr, L.C. 2006. Lower lethal temperature for adult male Diamesa mendotae Muttkowski (Diptera: Chironomidae), a winter-emerging Diamesinae. - Aquatic Insects 28 (1): 57-66.

Rieradevall, M. and Prat, N. 1999. Chironomidae from high mountain lakes in Spain and Portugal-. Hoffrichter, $O$. (ed.). Late 20th century Research on Chironomidae: An Anthology from the 13th International Symposium on Chironomidae. Shaker Verlag. Aachen, 605-613.

Hughes, S., Cabecinha, E., Andrade dos Santos, J., Mendes Andrade, C., Lopes, D., Trindade, H. et al. 2012. A predictive modelling tool for assessing climate, land use and hydrological change on reservoir physicochemical and biological properties. - Area 44 (4): 432-442.

Moreno, A., López-Merino, L., Leira, M., Marco-Barba, J., González-Sampériz, P., Valero-Garcés, B.L. et al. 2011. Revealing the last 13,500 years of environmental history from the multiproxy record of a mountain lake (Lago Enol, northern Iberian Peninsula). - Journal of Paleolimnology 46 (3): 327-349.

Montserrat, P. and Fillat, F. 1990. The systems of grassland management in Spain. In Managed grasslands. A. Breymeyer (ed.), Elsevier Science, Amsterdam, pp. 37-70.

Urquhart, E. 2002. Stonechats: A guide to the Genus Saxicola. A\&C Black Publishers: London, UK. 320pp.

Greig-Smith, P.W. 1983. Use of perches as vantage points during foraging by male and female stonechats Saxicola torquata. - Behaviour, 86, 215-236. 